\title{
PENERAPAN BLENDED LEARNING BERBANTUAN SCHOOLOGY UNTUK MENINGKATKAN KEAKTIFAN DAN PRESTASI BELAJAR MATEMATIKA SISWA KELAS VIII A1 SMP NEGERI 6 SINGARAJA
}

\author{
D.I. Purwitasari, I.W.P. Astawa, I.G.P. Sudiarta \\ Jurusan Matematika \\ Universitas Pendidikan Ganesha \\ Singaraja, Indonesia \\ e-mail: dwitayani.indri.purwitasari@undiksha.ac.id, puja.astawa@undiksha.ac.id,gussudiarta@undiksha.ac.id
}

\begin{abstract}
Abstrak
Penelitian dengan menerapkan Blended Learning berbantuan Schoology ini bertujuan untuk mengetahui peningkatan keaktifan dan prestasi belajar matematika siswa. Penelitian ini merupakan penelitian tindakan kelas yang dilaksanakan dalam tiga siklus yang masing-masing siklus terdiri dari empat tahap, yakni (1) perencanaan tindakan, (2) pelaksanaan tindakan, (3) observasi dan evaluasi, serta (4) refleksi. Subjek penelitian ini adalah siswa kelas VIII A1 SMP Negeri 6 Singaraja tahun ajaran 2018/2019 sebanyak 32 orang siswa. Pengumpulan data untuk keaktifan belajar siswa menggunakan lembar observasi sedangkan pengumpulan data prestasi belajar siswa menggunakan tes prestasi belajar berbentuk uraian. Hasil dari penelitian ini adalah persentase skor keaktifan belajar siswa mengalami peningkatan di setiap siklus yaitu $51,08 \%, 52,08 \%$, dan $62,74 \%$. Skor rata-rata dari tes prestasi belajar siswa dari siklus ke siklus yaitu 52,19; 85,16 dan 95,54 dimana 96,86\% siswa memperoleh skor diatas KKM pada akhir siklus. Hal ini menunjukkan bahwa penerapan Blended Learning berbantuan Schoology dapat meningkatkan keaktifan dan prestasi belajar siswa.
\end{abstract}

Kata Kunci:Blended learning, Schoology, keaktifan belajar, prestasi belajar

\begin{abstract}
The research by implementing Schoology's and assisted by Blended learning is aims to find out the improvement of students' activeness and mathematics learning achievement.This research is about class action that conducted in three cycles, define by four stages, which is (1) planning, (2) action, (3) observation and evaluation, and(4) reflection. The subjects of this study were class VIII A1 SMP Negeri 6 Singaraja at period 2018/2019 with total 32 students. Data for student learning activeness collected using observation sheets while data student learning achievement collect using form with detail descriptions. The results of this study are the percentage of students' learning activeness score has increased in each cycle, which is $51.08 \%, 52.08 \%$, and $62.74 \%$. The average score of the student achievement test from cycle to cycle is $52.19 ; 85.16$ and 95.54 where $96.86 \%$ of students score above the standard (KKM) at the end of the cycle. This shows that the application of Schoology-assisted Blended learning can improve student activity and learning achievement.
\end{abstract}

Keywords : Blended learning, Schoology, learning activeness, learning achievement

\section{PENDAHULUAN}

Perkembangan pendidikan di zaman digital ini menuntut siswa menjadi cerdas dan pandai serta memiliki daya saing tinggi selaras dengan perkembangan zaman pada abad 21 . Salah satu pembelajaran yang banyak diterapkan dalam dunia pendidikan adalah pembelajaran aktif (Active Learning).

Pembelajaran aktif adalah pembelajaran yang berpusat pada siswa (student centered learning) dimana pembelajaran ini mengajak siswa mendominasi aktivitas pembelajaran, mereka secara aktif menggunakan otak untuk menemukan ide-ide pokok materi pembelajaran, memecahkan masalah terkait materi dan menghubungkannya ke dalam kehidupan nyata. Dengan cara ini, siswa akan mendapatkan pembelajaran yang lebih menyenangkan sehingga dapat memaksimalkan hasil belajarnya terutama dalam 
pembelajaran matematika. Dalam Matematika pembelajaran yang aktif merupakan solusi untuk meningkatkan daya ingat termasuk daya tarik siswa untuk belajar, dan hal ini harus ditunjang dengan media pembelajaran yang menarik.

Namun pada kenyataanya matematika masih dianggap sulit untuk dimengerti dan membosankan. Konsep-konsep yang rumit menyebabkan siswa enggan untuk mencoba mengkontruksi pemahamannya. Hal ini mengakibatkan kurang aktifnya siswa untuk berpartisipasi dalam pembelajaran serta rendahnya prestasi belajar matematika siswa.

SMP Negeri 6 Singaraja adalah salah satu sekolah di Kabupaten Buleleng yang mengalami masalah dalam proses pembelajaran matematika khususnya di kelas VIII A1. Berdasarkan hasil observasi saat pembelajaran, wawancara dengan guru, serta pemberian angket kepada siswa ditemukan beberapa permasalahan yaitu pemahaman siswa yang berbeda-beda dalam menerima materi dengan waktu pembelajaran yang dirasa cukup singkat oleh guru dan siswa menyebabkan banyak materi yang belum dipahami. Banyak siswa kurang memerhatikan pelajaran karena siswa menganggap matematika adalah pelajaran yang membosankan dan sulit dimengerti sehingga siswa tidak memahami materi secara maksimal.

Saat pembelajaran di kelas banyak siswa yang kurang percaya diri mengemukakan pendapat, banyak yang terlihat ragu untuk mengacungkan tangan saat guru bertanya, hal ini menyebabkan kurangnya diskusi yang terjadi di dalam pembelajaran. Siswa sudah mampu menggunakan internet untuk menambah materi pembelajaran, ada beberapa siswa yang mencari materi di youtube hingga mengikuti bimbingan belajar online di ruang guru. Namun masih banyak siswa belum bisa menemukan materi yang sesuai dan tepat untuk pembelajaran sehingga mereka jarang mencari tambahan materi melalui internet.

Selain permasalahan-permasalahan yang telah ditemukan dalam proses pembelajaran, penulis juga mendapatkan hasil skor ulangan siswa untuk melihat prestasi belajar matematika siswa kelas VIII A1 SMP Negeri 6 Singaraja. Skor tertinggi yang diperoleh siswa adalah 100 dan skor terendah adalah 24, serta rata-rata skor di kelas VIII A1 adalah $67,75 \%$. Dari 32 orang siswa hanya 14 orang saja yang memenuhi KKM dan 18 orang mendapat skor dibawah KKM. KKM di SMP Negeri 6 Singaraja adalah 72, sehingga persentase ketuntasan di kelas tersebut hanya 43,75\%, ini berarti prestasi belajar matematika di kelas VIII A1 masih sangat rendah.

Permasalahan-permasalahan yang muncul di kelas tersebut menjadi faktor rendahnya keaktifan siswa ketika melaksanakan proses pembelajaran. Agar siswa dapat memahami konsep yang ada pada matematika siswa harus terlibat aktif dalam pembelajaran, tidak hanya bergantung pada penjelasan guru atau teman saja.Rendahnya keaktifan dan prestasi belajar perlu ditangani dengan pemilihan teknik pembelajaran yang tepat. Menciptakan suasana kelas yang lebih menyenangkan dan tidak monoton dapat meningkatkan keaktifan siswa di kelas yang serta prestasi belajarnya. Salah satu cara belajar yang dapat meningkatkan keaktifan belajar siswa dan prestasi belajarnya adalah blended learning.

Beberapa pendapat para ahli mengungkapkan mengenai pengertian blended learning adalah sebagai berikut. Cheung dan Hew (dalam Firmansyah, 2015:4) berpendapat bahwa blended learning sebagai kombinasi antara face to face learning dan online learning. Elenena Mosa (dalam Riyana, 2009:21) mengatakan bahwa yang dicampurkan dalam blended learning adalah dua unsur utama, yaitu pembelajaran di kelas (classroom lesson) dengan online learning. Purtadi (dalam Husamah, 2014: 18) menyatakan bahwa blended learning adalah kombinasi berbagai media pembelajaran yang berbeda yakni aktivitas, teknologi dan berbagai jenis peristiwa untuk menciptakan program pembelajaran yang optimum untuk siswa yang spesifik.

Menurut Hasbullah (2015:53), terdapat tiga komponen pembelajaran blended learning yaitu sebagai berikut.

\section{Online Learning}

Online learning adalah lingkungan pembelajaran yang menggunakan teknologi internet dan berbasis web dalam mengakses materi pembelajaran dan memungkinkan terjadinyai nteraksi 
pembelajaran antara sesama siswa atau dengan pengajar dimana saja dan kapan saja. Online learning memanfaatkan internet sebagai salah satu sumber belajar.

\section{Pembelajaran Tatap Muka (Face to face Learning)}

Pembelajaran tatap muka adalah salah satu bentuk model pembelajaran konvensional yang berupayamenyampaikan pengetahuan kepada siswa. Pembelajaran ini mempertemukan siswa dan pendidik dalam satu ruangan untuk belajar. Karakteristik dari pembelajaran tatap muka ini adalah terencana, berorientasi pada tempat, dan interaksi sosial. Beberapa macam metode yang digunakan dalam pembelajaran tatap muka yaitu metode ceramah, metode penugasan, metode tanya jawab, dan metode demonstrasi. Melalui pembelajaran tatap muka, siswa dapat lebih memperdalam apa yang telah dipelajari melalui online learning, ataupun offlinelearning untuk lebih memperdalam materi yang diajarkan melalui tatap muka.

\section{Belajar Mandiri}

Individualized learning adalah salah satu aktivitas dalam pembelajaran blended learning dimana siswa dapat belajar mandiri dengan cara mengakses informasi atau materi pembelajaran secara online dengan internet. Belajar mandiri memiliki arti belajar secara berinisiatif, dengan ataupun tanpa bantuan orang lain dalam belajar.

Seperti yang telah dikatakan oleh para ahli, model pembelajaran blended learning adalah pembelajaran yang menggabungkan pembelajaran tatap muka (face to face) dengan pembelajaran berbasis komputer atau secara online(Dwiyogo, 2018: 3). Hal ini berarti blended learning merupakan suatu pembelajaran dengan pendekatan teknologi yang mengkombinasikan sumber-sumber belajar pada tatap muka dengan pengajar maupun yang dimuat dalam media komputer, telepon seluler, televisi, konferensi video, dan media elektronik lainnya. Tujuan dari blended learning ini adalah memberikan kesempatan bagi berbagai karakteristik siswa agar terjadi belajar mandiri, berkelanjutan, dan berkembang sepanjang hayat, sehingga belajar akan lebih efektif, lebih efisien, dan lebih menarik.

Adapun manfaat dari blended learningyaitu sebagai berikut.1) Memungkinkan siswa untuk memiliki kesempatan yang sama dengan rekan mereka di bagian lain dunia. 2) Bahan pembelajaran dan proses pembelajaran menjadi lebih bervariatif dan menarik. 3) Memberikan keterampilan dasar guru dan siswa tentang pendidikan komputer dengan tujuan mengakses internet. 4) Membantu guru dan siswa berkomunikasi dengan nyaman di dunia global 5) Memfasilitasi pengajaran, penelitian dan penciptaan pengetahuan serta penyebaran informasi di dunia pendidikan. 5) Sebagai tempat praktik terbaik untuk menggunakan teknologi dan informasi (Umoh, 2014:61).

Dalam perkembangannya beberapa penulis menemukan bahwa blended learning atau pembelajaran online memiliki potensi yang baik untuk meningkatkan kemampuan kinerja siswa. Stenbom, Leong \& Alexander (dalam Sudiarta, 2017) mengungkapkan bahwa pembelajaran online untuk pekerjaan rumah berbasis web berperan penting dalam sikap siswa karena langsung mendapatkan umpan balik yang meningkatkan pemahaman. Cara ini efektif untuk meningkatkan partisipasi siswa saat berdiskusi dengan siswa lainnya maupun guru mereka, menghubungkan antara ide-ide matematika dan menggunakan apa yang telah dipelajari sebagai hasil dari pembelajaran matematika. Penelitian terbaru telah dilakukan dan diungkapkan bahwa pengalaman belajar dengan blended learning menguntungkan siswa yaitu memberi efek positif tidak hanya pada hasil belajar, tetapi juga pada sikap siswa terhadap matematika.

Hasil penelitian oleh Sudiarta, 2016 menyatakan bahwa proses pembelajaran secara online dengan materi pendukung berupa video yang menarik disediakan di website yang dapat diakses oleh siswa kapan saja selama 24 jam. Hal ini dapat membantu siswa dalam hal waktu dan tempat belajar. Siswa dapat mengulang video sebanyak yang dia mau sehingga siswa dapat memahami materi dengan baik. Dengan pembelajaran secara online dapat memberikan kepercayaan diri pada siswa sehingga siswa lebih siap dalam menerima pembelajaran secara tatap muka (Sudiarta,dkk 2016).

Penerapan blended learninginimengharapkan siswa dan guru aktif dan mampu menerapkan kegiatan belajar mengajar dimanapun dan kapanpun. Hal inilah yang 
merupakan daya tarik untuk para siswa karena akses untuk belajar yang tidak mengekang waktu, tempat dan kondisi. Keterlibatan siswa dalam kegiatan belajar mengajar akan meningkat, begitu pula dengan persaingan antar siswa akan terlihat dan terekam jelas sehingga memacu siswa untuk lebih berani terlibat dalam forum diskusi.

Banyak cara belajar yang bisa diterapkan pada blended learningini saat melaksanakan pembelajaran online, salah satunya adalah penggunaan Learning Management System (LMS) sebagai penunjang dalam pembelajaran online. LMS ini merupakan sistem pengelolaan pembelajaran secara integratif berbasis website. LMS yang digunakan sampai saat ini sudah banyak, salah satunya yaitu Schoology.

Schoology adalah Learning Management System untuk sekolah yang menawarkan pembelajaran seperti di kelas secara percuma dan visual dan fungsionalnya mudah digunakan seperti media sosial facebook. Laman yang dapat digunakan berupa catatan kehadiran, fasilitas utuk mengelola nilai, tes,kuis dan pekerjaan rumah (Firmansyah, 2015:3). Melalui Schoology siswa dapat belajar dengan menggunakan video tutorial maupun dokumen yang diunggah oleh guru sebagai pendalaman materi dan juga dapat mengadakan diskusi secara online.

Schoology sebagai media pembelajaran yang mungkin bisa membantu proses pembelajaran yang efektif. Dengan adanya media ini diharapkan dapat menarik perhatian siswa sebagai media pembelajaran baru dan menunjang minat siswa untuk belajar. Melalui pembelajaran berbasis blended learning yang berbantuan Schoology diharapkan siswa dapat belajar dengan mandiri dan siswa lebih berperan aktif dalam pembelajaran. Dalam Schoology siswa akan mengikuti diskusi, mengerjakan tes, mencari sumber belajar yang lain dan tidak hanya mengandalkan guru dalam memperdalam materi.

Blended learning berbantuan schoology dirasa dapat menjadi solusi yang tepat untuk memecahkan permasalaham yang terjadi di kelas VIII A1 karena dengan pengadaan kelas online diharapkan dapat memberikan waktu belajar yang lebih banyak untuk siswa sehingga siswa memiliki kesempatan belajar lebih banyak dibandingkan hanya belajar di kelas saja. Model pembelajaran blended learning berbantuan video tutorial yang diunggah di kelas schoology saat pembelajaran online diharapkan dapat membantu siswa untuk lebih memahami materi yang dipelajari serta meningkatkan rasa ketertarikan siswa untuk mempelajari matematika.

Model pembelajaran blended learning dengan melaksanakan kegiatan diskusi online diharapkan dapat mengajak siswa untuk lebih berani dalam bertanya saat tidak memahami pelajaran dan juga mau mengemukakan pendapat jika siswa malu mengatakan secara langsung di kegiatan tatap muka.Schoology menjadi salah satu wadah untuk siswa menambah pemahaman materi dan mempermudah siswa untuk mendapatkan materi yang sesuai dengan pembelajaran di sekolah.

Berdasarkan uraian di atas, peneliti tertarik untuk menerapkan blended learning berbantuan schoologydalam pembelajaran matematika melalui penelitian tindakan kelas. Penelitian ini bertujuan untuk mengetahui bagaimana peningkatan keaktifan dan prestasi belajar siswa kelas VIII A1 SMP Negeri 6 Singaraja dalam pembelajaran matematika setelah dibelajarkan dengan blended learningberbantuan schoology.

\section{METODE}

Jenis penelitian yang dilaksanakan ini merupakan penelitian tindakan kelas (Classroom Action Research), dilaksanakan di SMP Negeri 6 Singaraja. Subjek Penelitian adalah siswa kelas VIII A1 SMP Negeri 6 Singaraja pada semester genap tahun pelajaran 2018/2019 sebanyak 32 orang siswa yang terdiri dari 15 orang siswa laki-laki dan 17 orang siswa perempuan.. Penelitian jenis ini bertujuan untuk memperbaiki dan meningkatkan kualitas, proses, dan hasil pembelajaran matematika di kelas. Penelitian ini menggunakan PTK dengan Kurt lewin. Penelitian ini dilaksanakan dalam tiga siklus yang masing-masing siklus terdiri dari empat tahap, yakni (1) perencanaan tindakan, (2) pelaksanaan tindakan, (3) observasi dan evaluasi, serta (4) refleksi.Setiap siklus dilaksanakan secara online dan tatap 
muka. Pada saat tatap muka dilaksanakan selama 3 kali pertemuan yang terdiri 2 pertemuan untuk pelaksanaan tindakan dan 1 kali pertemuan untuk melakukan tes akhir siklus yang terdiri dari 4-5 butir soal uraian yang memuat materi yang dipelajari

Pada tahap perencanaan tindakan dilakukan beberapa kegiatan yaitu menyusun Rencana Pelaksanaan Pembelajaran (RPP) menggunakan blended learningberbantuan Schoology, menyiapkan media pembelajaran berupa web/aplikasi Schoology dan Lembar Kerja, serta menyusun instrumen untuk mengukur kemampuan siswa, yaitu keaktifan dan prestasi belajar yang dimiliki siswa.Pada tahap pelaksanaan tindakan ini, guru melaksanakan pembelajaran berdasarkan rencana pelaksanaan pembelajaran yang telah disusun atau dirancang pada tahap perencanaan.

Selama pelaksanaan tindakan kelas pada setiap siklus, dilakukan observasi dan evaluasi terhadap pelaksanaan tindakan pada setiap siklus tersebut. Peneliti melaksanakan tahap ini di kelas dan web/aplikasi Schoology. Observasi dilakukan selama proses pembelajaran berlangsung. Tujuannya adalah untuk mengetahui kelemahan dan kendala yang dihadapi serta keunggulan pada proses pembelajaran selama menerapkan model pembelajaran blended learningberbantuan Schoology. Evaluasi dilakukan untuk mengetahui hasil dari pelaksanaan tindakan. Evaluasi ini dilaksanakan terhadap sikap siswa selama pembelajaran berupa keaktifan belajar siswa serta evaluasi yang dilaksanakan di setiap akhir pembelajaran, sedangkan evaluasi di setiap akhir siklus diberikan tes prestasi belajar untuk mengamati prestasi belajar matematika siswa.

Pada akhir setiap siklus, peneliti melaksanakan refleksi. Refleksi yang dilaksanakan mengacu pada hasil yang diperoleh pada kegiatan observasi dan evaluasi selama proses pembelajaran. Peneliti mengkaji kembali kelemahan yang masih terjadi pada proses pembelajaran yang dilaksanakan. Hasil refleksi ini digunakan sebagai dasar memperbaiki dan menyempurnakan perencanaan dan pelaksanaan tindakan pada siklus berikutnya

Pengumpulan data terkait keaktifan belajar matematika siswa kelas VIII A1 SMP Negeri 6 Singaraja dilakukan dengan melaksanakan observasi secara tatap onlinedan tatap muka dengan menggunakan lembar observasi keaktifan belajar siswa. Lembar observasi keaktifan belajar siswa saatonline dan tatap muka memuat 10 indikator yaitu untuk kelas onlineterdiri dari kehadiran siswa di kelasonline, keaktifan dalam bertanya terkait materi yang dipelajari, keaktifan mengemukakan pendapat dalam menjawab soal, keaktifan mengemukakan menanggapi pertanyaan atau jawaban siswa lain,sedangkan di kelas tatap muka yaitu ketepatan kehadiran siswa, kesiapan siswa mengikuti pembelajaran, keaktifan dalam kemauan berdiskusi, perhatian terhadap pendapat teman, keaktifan dalam mengerjakan soal-soal serta keaktifan dalam mengemukakan pendapat (Firmasari, 2012).

Pengumpulan data terkait prestasi belajar matematika kelas VIII A1 SMP Negeri 6 Singaraja dilakukan dengan mengadakan tes di setiap akhir siklus. Adapun tes yang digunakan dalam pengumpulan data prestasi belajar siswa ini adalah tes dalam bentuk uraian dimana tes ini bertujuan agar siswa dapat menungkan ide-ide dalam menganalisis dan memecahkan permasalahan pada soal yang diberikan. Analisis data mengenai keaktifan belajar siswa berdasarkan skor tiap indikator menggunakan rumus sebagai berikut.

$$
\operatorname{Skor}(S)=\frac{S T M+S O}{m} \times 100 \%
$$

Keterangan :

$S=$ persentase skor keaktifan belajar siswa

$S T M=$ skor siswa di kelas tatap muka

$S O=$ skor siswa di kelas online

$m=$ skor maksimum penilaian

Analisis data prestasi belajar siswa dilaksanakan dengan menentukan rata-rata skor kemampuan prestasi belajar siswa dengan rumus berikut. 


$$
\bar{X}=\frac{\sum_{i=1}^{n} X_{i}}{n}
$$

Keterangan:

$\bar{X}=$ rata - rata skor kemampuan prestasi belajar siswa

$X_{i}=$ skor kemampuan prestasi belajarsiswa ke- $i$

$n$ = banyak siswa

Data prestasi belajar siswa yang diperoleh dikualifikasikan berdasarkan Kriteria Ketuntasan Minimal mata pelajaran matematika kelas VIII A1 SMP Negeri 6 Singaraja yaitu 72.Selain prestasi belajar yang dimiliki siswa ditinjau dari rata-rata skor prestasi belajar, dalam penelitian ini prestasi belajar siswa juga ditinjau Ketuntasan Belajar (KB). Adapun rumus dari Ketuntasan Belajar ini yaitu sebagai berikut.

$K B=\frac{\text { Banyak siswa yang mendapatskor } \geq 72}{\text { Banyaksiswa }} \times 100 \%$

Penelitian ini dikatakan berhasil jika rata-rata skor keaktifan belajar siswa minimal berada pada kategori baik, dan rata-rata nilai prestasi belajar siswaa pada kategori tuntas (nilai prestasi belajar $\geq 72$, meningkat dari siklus ke siklus), serta persentase ketuntasan belajar klasikal siswa mencapai $70 \%$ dari total keseluruhan siswa

\section{HASIL DAN PEMBAHASAN}

Berikut adalah ringkasan data keaktifan belajar siswa selama penelitian berlangsung, dari awal pelaksanaan siklus I sampai dengan akhir pelaksanaan siklus III.

Tabel 1. Ringkasan Data Keaktifan Belajar Siswa

\begin{tabular}{ccccc}
\hline Tahapan & Jumlah Skor & Persentase & Peningkatan & Kriteria \\
\hline Siklus I & 1471 & $51,08 \%$ & - & Cukup \\
Siklus II & 1509 & $52,38 \%$ & $1,3 \%$ & Cukup \\
Siklus III & 1807 & $62,74 \%$ & $10,36 \%$ & Baik \\
\hline
\end{tabular}

Hasil penelitian yang diperoleh pada siklus I yaitu persentase skor keaktifan belajar siswa sebesar 51,08 \% yang berada pada kategori "Cukup" namun masih belum mencapai batas minimum indikator keberhasilan yang telah ditetapkan. Pelaksanaan tindakan pada siklus II telah diperbaiki berdasarkan hasil refleksi pada siklus I.

Adapun perbaikan tindakan yang dilaksanakan pada siklus II yaitu: (1) Peneliti membantu siswa yang belum bisa login kembali dengan menemukan permasalahan yang membuat siswa tidak bisa login melalui diskusi di kelas maupun melalui chatting di aplikasi whatsapp. (2) Menjelaskan kembali cara berkomentar yang baik dan benar di akhir pertemuan tatap muka dengan memberikan tutorial singkat. (3) Mengingatkan siswa untuk saling memberikan informasi dan menjelaskan kepada anggota kelompoknya apabila ada anggota kelompok yang belum memahami materi yang sedang dibahas, bagi siswa yang belum paham harus bertanya lebih aktif lagi kepada teman kelompoknya yang sudah memahami materi. (4) Menjelaskan kembali materi yang belum dipahami siswa, dan juga memberikan kesempatan kepada siswa yang lebih dulu memahami materi di kelas online untuk menjelaskan kepada siswa lainnya lalu memberikan penghargaan kepada siswa yang mau menjelaskan materi dengan memberikan nilai tambahan, sehingga memancing siswa lain untuk mencoba memahami materi yang dibahas pada kelas online. (5) Mengalokasikan waktu dalam mengerjakan latihan soal dan pembahasannya dan mengingatkan siswa mengenai waktu 
yang telah ditetapkan. (6) Menjelaskan kepada siswa cara mengerjakan tes uraian dengan melatih siswa menuliskan jawaban latihan soal secara lengkap seperti menuliskan hal yang ditanyakan dan diketahui pada soal. Menekankan kembali mengenai rumus terkait materi di akhir pembelajaran.

Keaktifan dan prestasi belajar siswa pada siklus II telah megalami peningkatan namun tidak signifikan serta peningkatan pada prestasi belajar siswa. Persentase skor keaktifan belajar siswa sebesar 52,38 \% yang berada pada kategori "Cukup" namun masih belum mencapai batas minimum indikator keberhasilan yang telah ditetapkan. Pelaksanaan tindakan pada siklus III telah diperbaiki berdasarkan pada hasil refleksi pada siklus II. Adapun perbaikan yang dilakukan adalah 1) Guru dan peneliti menyarankan kepada siswa untuk tidak hanya berpatokan untuk bertanya materi saja namun juga boleh mengunggah materi untuk siswa lain tentang materi selain pada web Schoology untuk dibahas bersama. Siswa juga bisa menanyakan soal lain selain LKS yang diunggah serta siswa lain boleh memberikan pedapat terkait pertanyaan yang diunggah oleh temannya. 2)Guru menengahi permasalahan yang dihadapi siswa dengan memberikan penjelasan untuk saling menghargai pendapat teman agar tidak terjadi keributan antar anggota kelompok.

Keaktifan dan prestasi belajar siswa pada siklus III telah megalami peningkatan yang signifikan yaitu sebesar $10,36 \%$ serta prestasi belajar siswa juga telah meningkat. Persentase skor keaktifan belajar siswa sebesar $62,74 \%$ yang berada pada kategori "Baik" ini berarti telah mencapai batas minimum indikator keberhasilan yang telah ditetapkan.

Ringkasan data prestasi belajar matematika yang dimiliki siswa kelas VIII A1 SMP Negeri 6 Singaraja dari tahap refleksi awal, siklus I, siklus II, hingga siklus III disajikan pada Tabel 2 berikut.

Tabel 2. Ringkasan Data Prestasi Belajar Matematika Siswa

\begin{tabular}{|c|c|c|c|c|c|c|c|c|c|}
\hline \multirow{2}{*}{ No } & \multirow{2}{*}{ Kategori } & \multicolumn{2}{|c|}{$\begin{array}{c}\text { Refleksi } \\
\text { Awal }\end{array}$} & \multicolumn{2}{|c|}{ Siklus I } & \multicolumn{2}{|c|}{ Siklus II } & \multicolumn{2}{|c|}{ Siklus III } \\
\hline & & $\mathrm{F}$ & $P$ & $F$ & $P$ & $F$ & $P$ & $F$ & $\mathrm{P}$ \\
\hline 1. & $\begin{array}{l}\text { Belum } \\
\text { Tuntas }\end{array}$ & 18 & $56,25 \%$ & 26 & $81,25 \%$ & 6 & $18,75 \%$ & 1 & $\%$ \\
\hline 2. & Tuntas & 14 & $43,75 \%$ & 6 & $18,75 \%$ & 26 & $81,25 \%$ & 31 & $96,86 \%$ \\
\hline & $\begin{array}{c}\text { ata-Rata } \\
\text { Skor }\end{array}$ & & 67,75 & & 52,19 & & 85,16 & & 95,54 \\
\hline & ningkatan & & - & & $-15,56$ & & 28,97 & & 14,38 \\
\hline & $\begin{array}{l}\text { Beluntasan } \\
\text { Blasikar } \\
\text { Klal }\end{array}$ & & $3,75 \%$ & & | 8,75\% & & $31,25 \%$ & & $96,86 \%$ \\
\hline
\end{tabular}

$$
\begin{aligned}
& \text { Keterangan : } \\
& F=\text { Frekuensi } \\
& P=\text { Persentase }
\end{aligned}
$$

Berdasarkan Tabel 2 di atas, dapat dilihat bahwa prestasi belajar matematika yang dimiliki siswa kelas VIII A1 SMP Negeri 6 Singaraja mengalami penurunan dari refleksi awal ke siklus I namun mengalami peningkatan dari siklus I ke siklus selanjutnya. Adapun penurunan rata-rata skor prestasi belajar yang dimiliki siswa dari refleksi awal ke siklus I 
adalah sebesar $15,56 \%$, dari siklus I ke siklus II meningkat sebesar 28,97 , dan dari siklus II ke siklus II adalah sebesar 14,38.

Pada pelaksanaan tindakan siklus I ini terdapat perubahan cara belajar dari metode ceramah menjadi belajar mandiri dimana siswa dituntut untuk aktif belajar secara mandiri di luar jam sekolah melalui pembelajaran online dengan diimbangi pembelajaran tatap muka di sekolah. Namun perubahan ini menyebabkan beberapa siswa kesulitan dalam belajar karena belum terbiasa untuk belajar secara mandiri. Siswa masih belum terbiasa untuk menggunakan fasilitas belajar secara online dan masih di dominasi oleh siswa yang memang aktif dari awal pembelajaran. sehingga pelaksanaan blended learningberbantuan schoology masih kurang optimal.

Pada siklus II siswa mulai terbiasa dengan belajar menggunakan blended learning. keaktifan di dalam pembelajaran tatap muka sudah menunjukkan adanya peningkatan. Siswa-siswa yang kurang memperhatikan penjelasan guru dan temannya sudah mulai memperhatikan serta mulai berani untuk bertanya dan berpendapat.

Namun pada kelas online keaktifan terlihat menurun dari siklus I karena siswa merasa sudah paham akan materi yang dibahas sehingga mereka tidak bertanya pada kelas online dan lebih banyak berpendapat mengenai latihan soal yang dikerjakan di kelas tatap muka, siswa hanya mengisi absen saja tanpa bertanya dan berpendapat pada kelas online.

Hasil tes prestasi meningkat drastis daripada siklus I, terlihat dari jawaban siswa yang lengkap dan memahami isi materi sehingga hanya beberapa orang saja yang nilainya di bawah KKM.

Pada siklus III peneliti menyarankan kepada siswa untuk tidak hanya berpatokan untuk bertanya materi saja namun juga boleh mengunggah materi untuk siswa lain tentang materi selain pada web schoology untuk dibahas bersama. Siswa juga bisa menanyakan soal lain selain LKS yang diunggah serta siswa lain boleh memberikan pedapat terkait pertanyaan yang diunggah oleh temannya. Pada siklus III ini proses pembelajaran di kelas online maupun tatap muka telah mengalami peningkatan. Hasil tes prestasi belajar juga meningkat dari siklus sebelumnya, dengan menerapkan blended learning berbantuan schoology siswa memiliki waktu belajar lebih banyak daripada hanya dengan pertemuan tatap muka. Soal-soal yang dibahas lebih banyak dan meningkatkan pemahaman materi siswa sehingga siswa mampu menjawab soal tes dengan baik dan benar.

Setelah melakukan perbaikan-perbaikan pada proses pembelajaran dari siklus I, siklus II dan siklus III, siswa menjadi lebih aktif dalam pembelajaran. Pada siklus III tidak lagi terdapat kendala yang berarti. Pembelajaran di setiap siklus semakin membaik sehingga pemahaman siswa terhadap materi yang sedang dipelajari juga semakin meningkat sesuai dengan yang direncanakan. Penerapan Blended learning berbantuanSchoologydalam pembelajaran matematika di kelas VIII A1 SMP Negeri 6 Singaraja sudah berjalan dengan lancar. Kendala-kendala yang dihadapi di setiap siklus dapat diperbaiki melalui refleksi proses pembelajaran sehingga terjadi peningkatan pada keaktifan dan prestasi belajar siswa dalam proses pembelajaran di setiap siklusnya.

Peningkatan yang terjadi karena siswa telah terbiasa dengan penerapan blended learningselama tiga siklus ini, dan juga waktu belajar siswa lebih banyak dibandingkan hanya dengan pertemuan tatap muka sehingga siswa lebih memahami materi yang sedang dibahas. Hal ini sejalan dengan penelitian dari Rihatul, L (2015) dan Galang, A (2016) melakukan penelitian terkait dengan penggunaan model pembelajaran blended learning. Lina menyatakan bahwa terdapat pengaruh yang signifikan dalam pembelajaran bauran (blended learning) terhadap motivasi belajar siswa yang berarti pembelajaran blended learning lebih baik daripada pembelajaran konvensional. Sedangkan Akhbar menyimpulkan bahwa hasil belajar siswa pada kelas dengan menggunkanan model pembelajaranblended learning lebih baik daripada hasil belajar pada kelas yang dibelajarkan secara konvensional.

Berdasarkan pemaparan tersebut penerapan Blended learning berbantuanSchoologytelah berhasil meningkatkan keaktifan dan prestasi belajar matematika siswa. 


\section{SIMPULAN DAN SARAN}

Berdasarkan uraian hasil penelitian dan pembahasan yang telah dipaparkan pada bab sebelumnya, dapat disimpulkan beberapa hal sebagai berikut.

Pelaksanaan pembelajaran dengan menerapkan Blended learning berbantuan Schoologydapat meningkatkan keaktifan belajar matematika siswa kelas VIII A1 SMP Negeri 6 Singaraja. Pada siklus I persentase skor keaktifan belajar yang diperoleh siswa sebesar $51,08 \%$ dan berada pada kriteria cukup. Kemudian dilakukan beberapa perbaikan dalam pelaksanaan pembelajaran, yaitu: 1) adanya perbaikan dengan menjelaskan kembali cara login dan berkomentar yang baik dan benar; 2) memberikan kesempatan kepada siswa untuk menjelaskan materi kepada siswa lainnya untuk menambah pemahaman materi; dan 3) mengalokasikan waktu agar kegiatan pembelajaran berjalan lebih efektif. Perbaikan tersebut dapat meningkatkan keaktifan belajar siswa pada kelas tatap muka namun belum meningkatkan keaktifan pada kelas onlineyakni terlihat persentase keaktifan pada siklus II $52,38 \%$ dan berada pada kriteria cukup. Setelah pelaksanaan siklus II, kembali dilaksanakan perbaikan dan penyempurnaan dalam pelaksanaan pembelajaran. Perbaikan tersebut antara lain: Guru dan peneliti menyarankan kepada siswa untuk tidak hanya berpatokan untuk bertanya materi saja namun juga boleh mengunggah materi untuk siswa lain tentang materi selain pada web schoology untuk dibahas bersama. Siswa juga bisa menanyakan soal lain selain LKS yang diunggah serta siswa lain boleh memberikan pedapat terkait pertanyaan yang diunggah oleh temannya.. Perbaikan dan penyempurnaan ini dapat meningkatkan kembali keaktifan belajar siswa terlihat dari persentase skor keaktifan belajar siswa meningkat secara signifikan menjadi $62,74 \%$ dan berada pada kriteria baik.

Pelaksanaan pembelajaran dengan menerapkan Blended learning berbantuan Schoologydapat meningkatkan prestasi belajar matematika siswa kelas VIII A1 SMP Negeri 6 Singaraja. Pada siklus I rata-rata skor prestasi belajar yang diperoleh siswa yaitu 52,19, persentase banyaknya siswa yang tuntas hanya sebesar $18,75 \%$ ( 6 orang orang). Berdasarkan hasil tersebut peneliti dan guru melakukan perbaikan dengan memberikan latihan soal yang dapat membantu pemahaman siswa serta menjelaskan cara menjawab soal uraian dengan Perbaikan tersebut dapat meningkatkan prestasi belajar siswa yakni terlihat pada siklus II terjadi peningkatan rata-rata skor prestasi belajar menjadi 85,16 dan persentase banyaknya siswa yang tuntas sebesar $81,25 \%$ (26 orang). Pelaksanaan tindakan pada siklus III telah diperbaiki berdasarkan pada hasil refleksi pada siklus II. Rata-rata skor prestasi belajar matematika siswa pada siklus I adalah 95,54 ini menunjukkan bahwa ratarata prestasi belajar siswa meningkat yaitu berada Ketuntasan belajar siswa secara klasikal adalah 96,86\%, sebanyak 31 dari 32 siswa saja yang telah mencapai skor di atas KKM.

Peneliti menyarankan kepada guru pengajar untuk menggunakan Blended learningberbantuanSchoology dalam pembelajaran matematika sebagai salah satu alternatif meningkatkan keaktifan dan prestasi belajar siswa.

\section{UCAPAN TERIMAKASIH}

Ucapan terima kasih peneliti sampaikan untuk semua pihal yang telah membantu dalam penelitian ini baik secara langsung maupun tidak langsung sehingga penelitian ini berjalan lancar dan peneliti berharap artikel ini dapat bermanfaat.

\section{DAFTAR PUSTAKA}

Dwiyogo W. 2018. Pembelajaran Berbasis Blended learning. Tersedia pada www.pembelajaranvisioner.com. (Diakses 16 November 2018)

Firmansyah, B. 2015. Pengembangan Blended learning Berbasis Schoology. Malang: Universitas Negeri Malang

Galang, A. 2016. Penggunaan Model Pembelajaran Blended learning terhadap Hasil Belajar Matematika Kelas VIII di SMPN 38 Surabaya. Tersedia pada https://reseacrhgate.net/publication. (Diakses 11 November 2018) 
Hasbullah. 2015.Blended learning Trend Strategi Pembelajaran Matematika Masa Depan. Tersedia pada http://josedia urnal.Ippmunindra.ac.id/index.php/Formatif/article/view/140. (Diakses 1 November 2018)

Husamah. 2014. Pembelajaran Bauran (Blended learning). Jakarta: Prestasi Pustaka

Riyana, C. 2009. Pedoman Bagi Guru. Tersedia pada http://kurtek.upi/edu/tik/content/ blended.pdf. (Diakses pada 1 November 2018)

Rihatul, L. 2017. Pengaruh Pembelajaran Bauran (Blended learning) terhadap Motivasi Siswa pada Materi Relasi dan Fungsi. Tersedia pada https://scholar.google.co.id. (Diakses 11 November 2018)

Sudiarta, Dkk. 2016. Pengaruh Model Blended Learning Berbantuan Video Animasi Terhadap Kemampuan Pemecahan Masalah Dan Pemahaman Konsep Siswa. Tersedia pada https://scholar.google.co.id/citations?user=V5TrlsAAAAJ\&hl=en(diakses pada 5 Januari 2019)

Sudiarta, Dkk. 2017. Investigation on students' mathematical online discussion: Acase study in grade 8 SMPN 1 Denpasar. International Conference on Mathematics and Natural Sciences.

Umoh, J. B. 2014. Challenges of Blended E-Learning Tools in Mathematics: Students'Perspectives University of Uyo. Canadian Center of science and education 